\title{
DEVELOPMENT OF THE THRESHING MACHINE FOR IMPROVING ITS PERFORMANCE UNDER EGYPTIAN CONDITIONS
}

E. A. El Saiedy ${ }^{*}$

\author{
G.R.Gamea**
}

Adel M. El Ashker ${ }^{* * * *}$

\begin{abstract}
To improve the performance of the locally manufactured threshing machines, a feeding system was developed to use with it. The aim of this work is to reduce both the threshing costs and the injuries to the laborers.
\end{abstract}

The main objectives of this study are:

1-Develop a feeding system for threshing machine.

2-Evaluat the performance of the threshing machines before modification at three moisture contents for wheat crop 17.2, 15.2 and $13.4 \%$ and four drum speeds 700, 800, 900 and $1000 \mathrm{rpm}$ (27.47, 31.4, 35.3 and $39.25 \mathrm{~m} / \mathrm{s}$ ).

3-Test the threshing machines after modification under the same conditions at different angels of conveyor belt of 17.5, 20, 23 and 26 degree.

The experimental results showed that the performance of a threshing machine after modification is better than before modification. The value of the feeding rate after modification increased about $26 \%$ than before modification. It was of $2.28 \mathrm{ton} / \mathrm{h}$ compared to $1.68 \mathrm{ton} / \mathrm{h}$ before modification. Threshing efficiency of $99.50 \%$, cleaning efficiency of 99.70 $\%$, unthreshed grain losses of $0.50 \%$, grain losses in straw of $0.30 \%$, grain damage of $0.65 \%$, cutting length of straw of $1.20 \mathrm{~cm}$, total grain losses of $5.37 \mathrm{~kg} / \mathrm{ton}$ were also recorded before modification. The operation cost was $22.8 \mathrm{LE} /$ ton and the threshing cost was $36.4 \mathrm{LE} /$ ton after the addition of the costs of lost grains at drum speed of $1000 \mathrm{rpm}$. These results were obtained at moisture content of $13.4 \%$, and conveyor belt angle of 20 degree.

\footnotetext{
*Lecturer. Dept of Ag. Eng., Fac. of Ag., Minoufiya Univ., Egypt. **Asso Prof.Dept of Ag. Eng., Fac. of Ag., Minoufiya Univ., Egypt. ***Assist Researcher, Ag. Eng. Res.Ins. Dokki, Giza, Egypt.
} 
On the other hand the results before modification threshing efficiency it was of $98.20 \%$, cleaning efficiency of $98.40 \%$, unthreshed grain losses $1.80 \%$, grain losses in straw of $1.00 \%$, grain damage of $2.10 \%$, cutting length of straw of $1.8 \mathrm{~cm}$, total grain losses of $18.13 \mathrm{~kg} / \mathrm{ton}$ were recorded. The operation cost was $33.33 \mathrm{LE} / \mathrm{ton}$ and threshing cost was $79.2 \mathrm{LE} / \mathrm{ton}$ after the addition of the costs of lost grains at drum speed of $1000 \mathrm{rpm}$ and moisture content of $13.4 \%$. The specific energies were 11.3 and 8.1 $\mathrm{kW} . \mathrm{h} / \mathrm{ton}$ before and after modification at the same previous conditions.

\section{INTRODUCTION}

7 he cultivated area of wheat crop In Egypt at the year 2012 owing to Ministry of Agriculture was about 2.81 million Feddans. The

1 Egyptian farmers usually use a local threshing machine to thresh their wheat. Many small workshops and manufactures produce threshing machines without any scientific guidance. Beside that, no feeding device was attached with the threshing machine, which makes feeding operation difficult and danger. For these reasons, it was necessary to develop a feeding device attached with the local manufactured threshing machine to increase its efficiency and to decrease total grain losses, energy, and total threshing cost. El - Mufti et al. (1989) reported that feeding crop without safety was one of the main reasons attributed to thresher injuries; they added also that the mechanical failures responsible for injuries were 17 \%. Mohan and Patel (1992) stated that in India the mechanization of agricultural practices resulted in increased agricultural productivity but at the same time the incidence of traumatic injuries among agricultural workers seems to have increased also. Among these, threshing machines are responsible for a significant number of serious injuries. Abo El-Naga et al. (2004) reported that, increasing drum speed increased seed damage, while decreased both unthreshed seed and total seed losses. On the other hand, increasing feed rate decreased seed damage, while increased both unthreshed seed and total seed losses. It was showed also that increasing seed moisture content decreased seed damage, while unthreshed seed and consequently total seed losses increased. Khattab et al. (2007) developed a feeding device constructed and attached with a Turkish threshing machine and it was found that, Minimum total grain losses of 5.48 and 
$3.57 \%$ before and after development were obtained at material-feed rate of $1100 \mathrm{~kg} / \mathrm{h}$, drum speed of $27 \mathrm{~m} / \mathrm{s}$ and grain moisture content of $19 \%$. While both threshing and cleaning efficiencies of $97.74,94.34 \%$ and 98.35, 97.25\% were obtained before and after development at the same previous conditions. The minimum value of threshing cost of 35.53 and $30.46 \mathrm{~L} . \mathrm{E} / \mathrm{ton}$ before and after development was obtained at material feed rate of $1100 \mathrm{~kg} / \mathrm{h}$; drum speed of $27 \mathrm{~m} / \mathrm{s}$ and grain moisture content of 19 $\%$.The energy requirements of 18.26 and $18.92 \mathrm{~kW}$.h/ton were obtained before and after development at the same previous conditions. Daghan et al. (2012) stated that, Technologies used to increase productivity in agriculture require the intense use of farming machines. In the literature, injuries due to farming machines including corn-picker, wheat thresher, grain auger, or hay baler have been reported. These accidents in agricultural enterprises result in income loss, production loss, material defects in devices, and high expenditures due to physical disabilities. He most commonly observed injury was the 5th degree injury and the most commonly affected fingers in this group were the third and fourth fingers while 14 of the patients had left upper extremity injury, 10 had right upper extremity injuries.

\section{MATERIALS AND METHODS}

\section{(A) Materials}

\section{Threshing machine specifications:}

The threshing machine used in this study was (CETINEL 120. Locally Manufacture). The specifications of the machine are shown in Table (1), fig. (1).

\section{Developed machine:}

\section{(a) Conveyor's frame}

The conveyor's frame was manufactured from two channels steel $10 \times 10$ $x 0.5 \mathrm{~cm}$ with length of $150 \mathrm{~cm}$ attached to the threshing machine by 2 bolts of $2.4 \mathrm{~cm}$ to change the angle of conveyor belt.

\section{(b) Conveyor}

The conveyor was made of special plastic and rubber 6 ply rating. The conveyer dimensions were $349 \mathrm{~cm}$. length $\times 116 \mathrm{~cm}$ width $\times 0.5 \mathrm{~cm}$ thicknesses. 


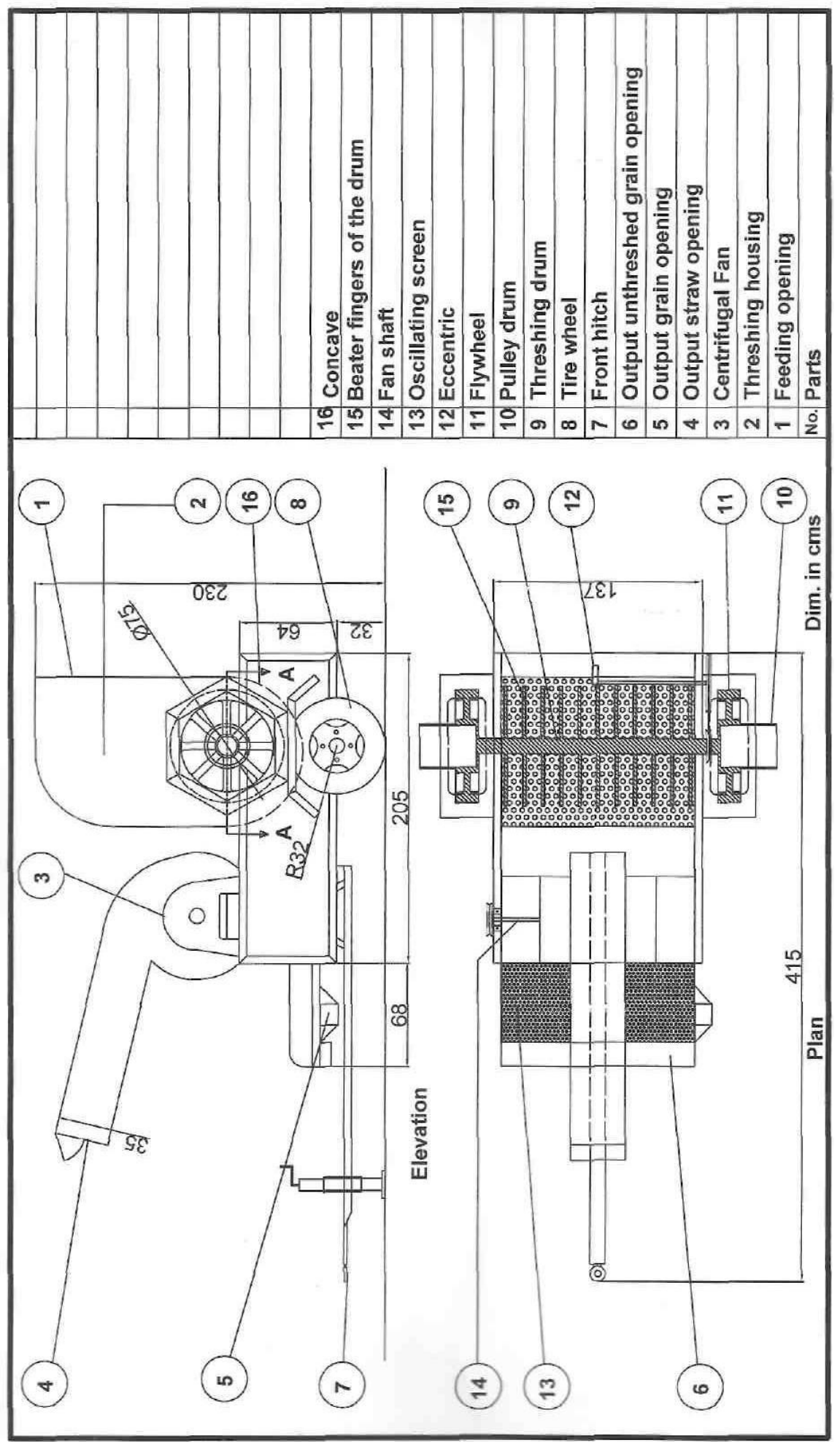

טే. 
Table (1): Specifications of threshing machine

\begin{tabular}{|c|c|}
\hline Items & threshing machine ( CETINEL-120) \\
\hline Length, cm & 320 without hitch, 415 with hitch \\
\hline Width, cm & 127 \\
\hline Height, cm & 198 \\
\hline Weight, kg & 1550 \\
\hline Source of power & Transmit from tractor through pulley and belt. \\
\hline Threshing knives & Spike tooth \\
\hline Length of the cylinder, $\mathrm{cm}$ & 118 \\
\hline Diameter of the cylinder, $\mathrm{cm}$ & 75 \\
\hline Cylinder knives & Total of $44 \mathrm{knives}, 32.5 \mathrm{~cm}$ long, 10 and 6 bottom and top \\
\hline Crop inlet, $\mathrm{cm}$ & $120 \times 45$ \\
\hline Grain outlet, $\mathrm{cm}$ & $10 \times 10$ \\
\hline Hole diameter for curved shaker & 1.5 \\
\hline
\end{tabular}

Both the ends of the conveyor were welded by leaser instrument using computer program. Also, seven supporting bars of rubber $1 \mathrm{~cm}$ width $\mathrm{x}$ $0.5 \mathrm{~cm}$ thickness $\mathrm{x} 116 \mathrm{~cm}$ length were fixed on the flat belt to control uniformity of the crop materials during the feeding process and decrease crop slipping. Fig (2) shows the conveyor and its components.

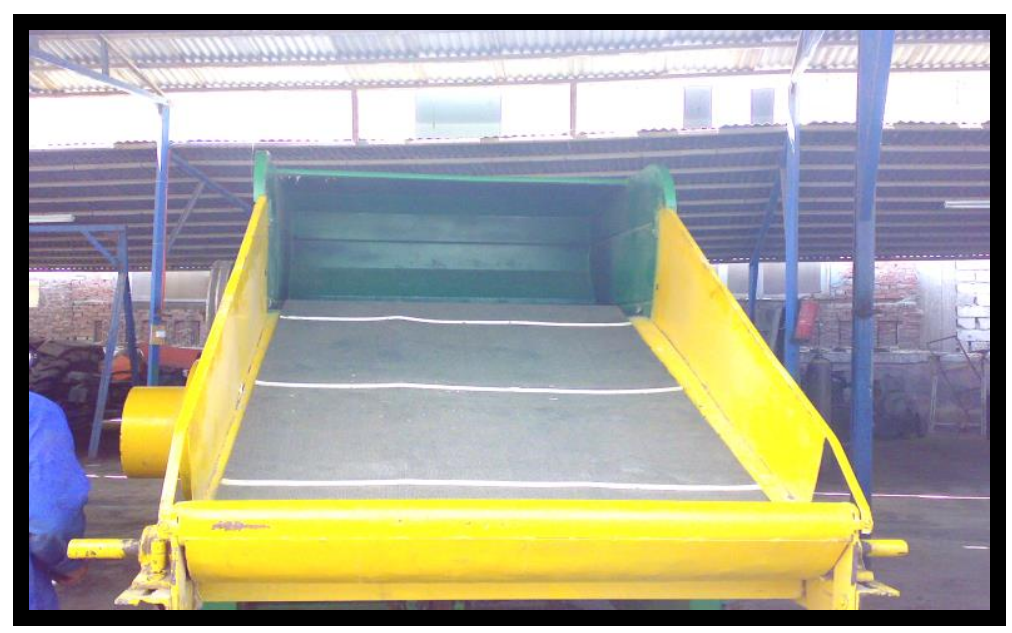

Fig (2): The conveyor belt. 


\section{(c) Drive drum}

The idler drive was made of steel pipe with diameter of $7.5 \mathrm{~cm}$, thickness of $0.4 \mathrm{~cm}$ and length of $116 \mathrm{~cm}$. Two flanges with diameter of $10 \mathrm{~cm}$ were welded at both edges of the drum to prevent the conveyer to slip and two guides on both drum. An axle of $5 \mathrm{~cm}$ diameter and $150 \mathrm{~cm}$ length was fixed along the center of the drum and welded outer of the two flanges. The drive drum axle was rolled on two ball bearing housing and equipped with double ball bearing and greaser. The bearing housing equipped with threaded bolt to adjust the tension of the conveyer. The motion was transferred to the drive drum via a pulley of $14 \mathrm{~cm}$ diameter.

\section{(d) Driven drum}

The driven drum was made of steel pipe with diameter of $7.5 \mathrm{~cm}$. thickness of $0.4 \mathrm{~cm}$. and length of $116 \mathrm{~cm}$. Two flanges with diameter of $10 \mathrm{~cm}$ were welded at both edges of the drum to prevent the conveyer to slip. An axle of diameter $5 \mathrm{~cm}$ and $140 \mathrm{~cm}$ length was fixed along the center of the drum and welded outer of the two flanges. The driven drum axle was rolled on two ball bearing hosing equipped with double ball bearing and greaser. Fig (3) shows a cross section in the drive drum bearing housing and conveyer tension.

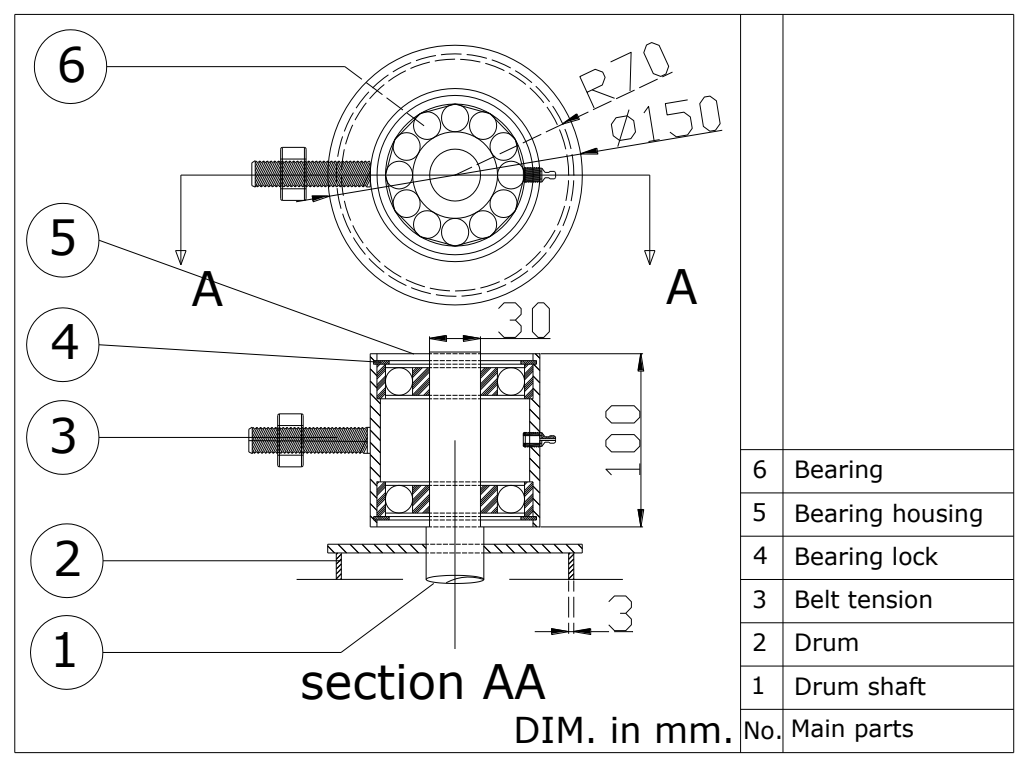

Fig (3): Drive and driven drums bearing housing and conveyer tension. 
(e) Balance of conveyor belt

In order to prevent deviation of the conveyor belt right or left during operation, 2 pulleys of $30 \mathrm{~cm}$ diameter welded from the end of each drum in both the drive and driven drum. $2 \mathrm{v}$ belts of $1.7 \mathrm{~cm}$ width and $349 \mathrm{~cm}$; lengths were fixed on inner surface of the conveyor belt so that the course of a pulley constantly lieutenants and don't not deviate from conveyor belt. The belts were welded by leaser instrument using computer program.

\section{Transmission system}

It was necessary to transmit motion to conveyor from the rote axle via a pulley of $14 \mathrm{~cm}$ diameter. It was fitted on it. The drive pulley transmits the motion to the driven axle of $40 \mathrm{~cm}$ diameter by a (V belt). Figs. 4, 5 and 6 shows the transmission system and main components after modification.

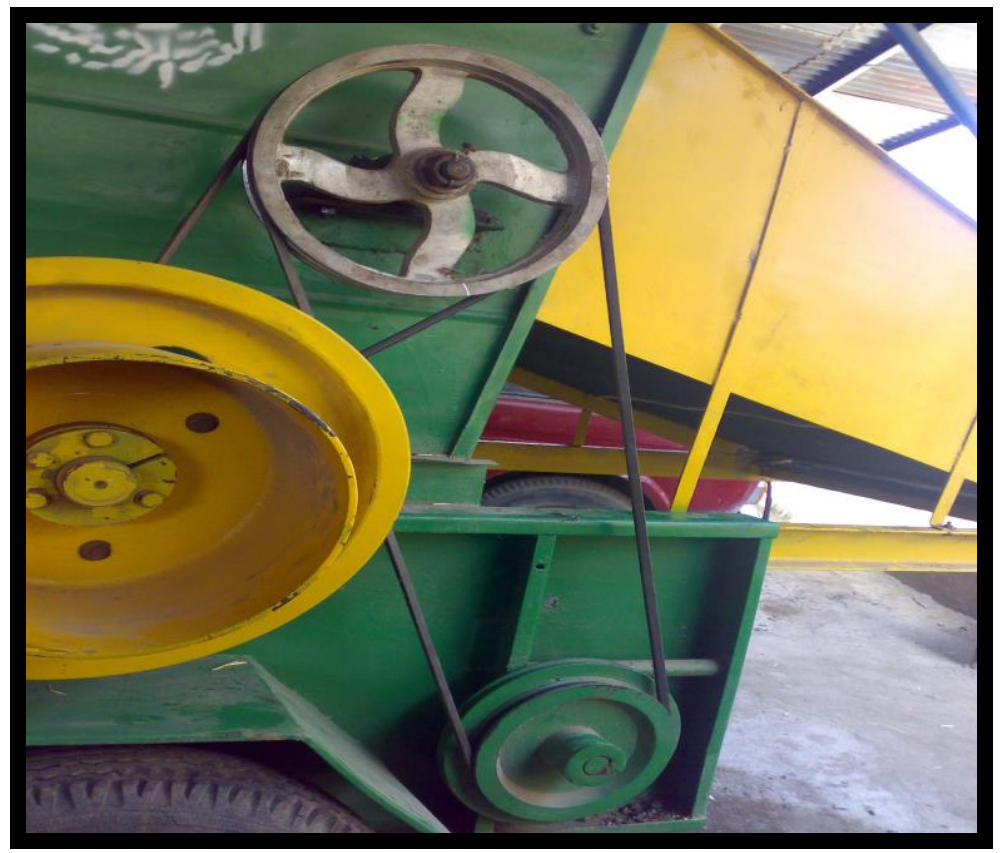

Fig. (4): Transmission system after modification.

\section{Tractor:}

A Nasr tractor of $60 \mathrm{hp}$ was used for operating CETINEL-120 threshing machine. The tractor power was transmitted to the threshing machine through tractor pulley by using rubber belt. 


\section{Crop}

The crop used in this study was wheat variety of Gemiza 9. The Grain straw ratio of this variety was (1:1.7).

\section{(B) Methods:}

\section{1 -Scope of variables}

The experimental work were carried out mainly to determine the effects of conveyor belt speed, angle of conveyor belt on machine capacity, threshing efficiency, length of cut straw, grain losses damaged and fuel consumption. The following variables were investigated:

I-Drum speeds: four speeds were tested before and after the modification of the threshing machine. It was 700, 800, 900 and $1000 \mathrm{rpm},(27.47$, $31.4,35.3$ and $39.25 \mathrm{~m} / \mathrm{s})$.

II- Angles of conveyor belt of were 17.5, 20, 23 and 26 degree.

III- The moisture content ratios of the crop were 17.2, 15.2 and $13.4 \%$.

\section{2-Experimental procedure}

2.1-Before the feeding process was conducted the following steps were done:

A- Adjusting the machine balance (horizontally - vertically) by a water balance for the modified and unmodified threshers.

B- Adjusting the shaker angle for the machines.

C- Crop sample of $200 \mathrm{~kg}$ was weight to do the experiments (bundle of $3 \mathrm{~kg}$ approximately).

2.2-The angle of the conveyor was adjusted by means of bolts.

2.3-The belt which transmits the motion between the tractor and the machine was also adjusted.

2.4-The threshing machine speed was adjusted by measured of digital tachometer.

2.5-The speeds of the belt, shaker and the cleaning fan also were measured.

2.6-The feeding process was done according to the previous operating conditions and controlling the following parameters.

A- Feeding rate from the feed opening to the threshing drum.

B- The threshing efficiency of the threshing drum.

2.7- Measuring the threshing time of each sample.

2.8- Each experiment was repeated three times. The following parameter was measured. 


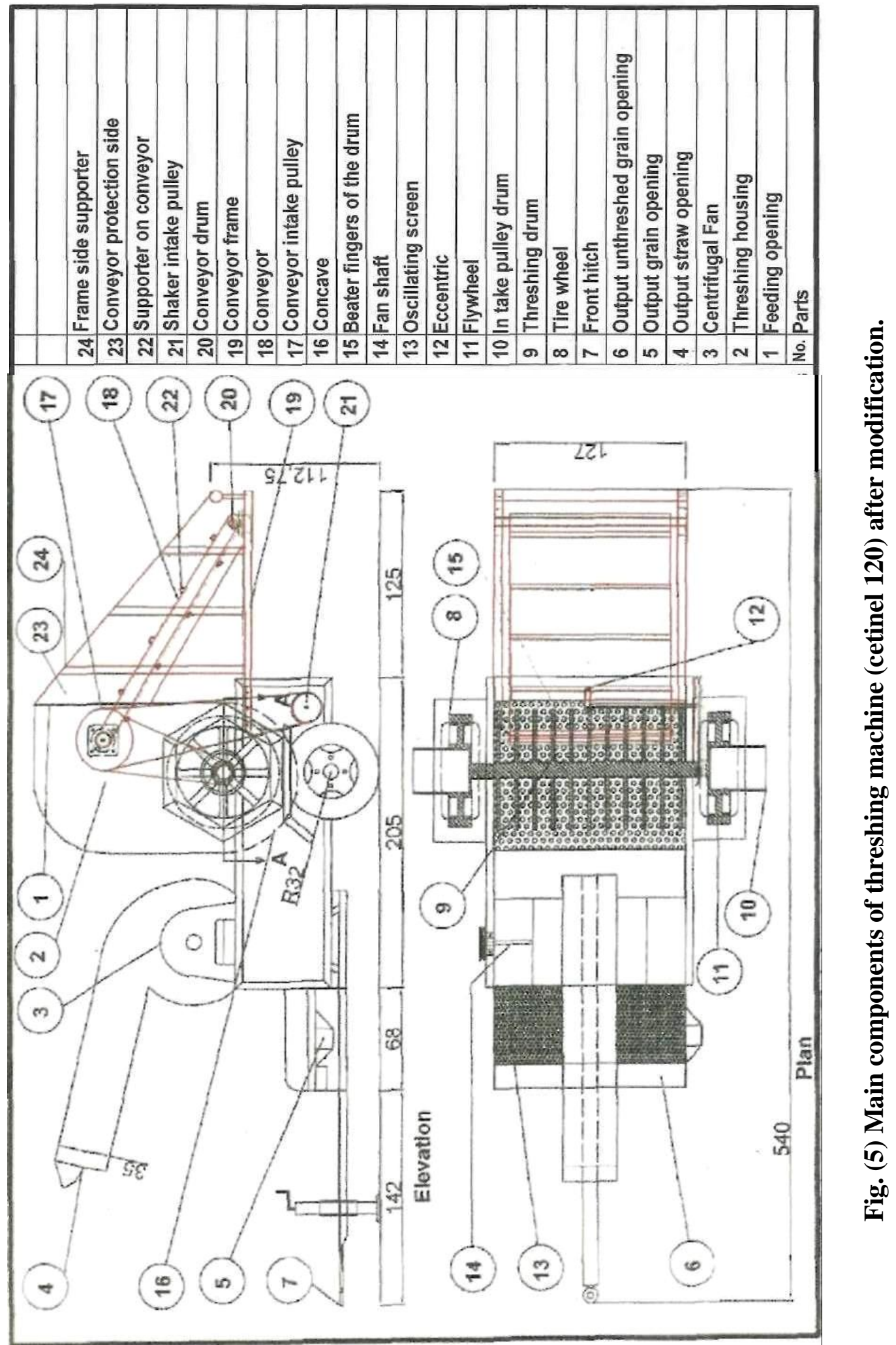



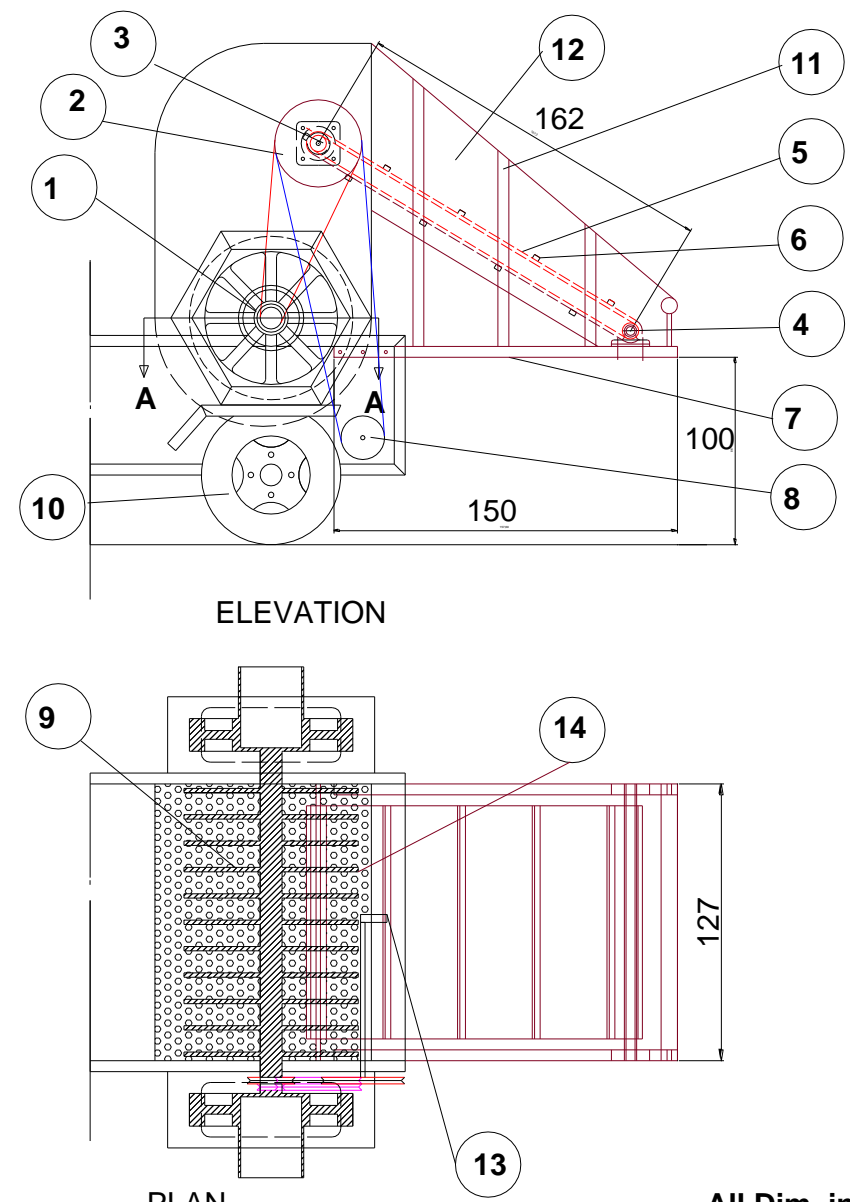

PLAN

All Dim. in cms

\begin{tabular}{|l|l|l|l|l|l|}
\hline No. & Part name & No. off & No. & Part name & No. off \\
\hline 1 & Feeding shaft & 1 & 8 & Shaker intake pulley & 1 \\
\hline 2 & Conveyor intake pulley & 1 & 9 & Threshing drum & 1 \\
\hline 3 & Idler shaft & 1 & 10 & Wheel & 1 \\
\hline 4 & Idle shaft & 1 & 11 & Frame side supporter & 1 \\
\hline 5 & Conveyor & 1 & 12 & Conveyor protection side & 1 \\
\hline 6 & Supporter on conveyor & 7 & 13 & Eccentric & 1 \\
\hline 7 & Conveyor frame & 1 & 14 & Beater fingers of the drum & 44 \\
\hline
\end{tabular}

Fig. (6 ): Elevation and plan of the developed feed device in a CETINEL threshing machine
A- Feeding rate $\mathrm{kg} / \mathrm{min}$.
B- Grain losses in straw
C- Unthreshed grain losses \% 
D- Grain damage $\%$.

E- Cleaning efficiency $\%$

F- Fuel consumption lit/h.

G- Length of cut straw $\mathrm{cm}$.

2.9-All the previous processed were done with the modified and the unmodified machine after changing the threshing drum speed to $700,800,900$, and 1000 r.p.m. and changing the conveyor angle to $17^{\circ}, 20^{\circ}, 23^{\circ}$, and $26^{\circ}$

2.10-One labor was used for the feeding process for the modified machine and two labors were used with the unmodified machine.

\section{Measurements and calculation}

\section{Moisture content.}

Plant samples were oven dried at $70^{\circ} \mathrm{C}$ for $72 \mathrm{~h}$ by using hot air oven. The samples were weighed before and after drying and the moisture content was determined by using the equation of AOAC (1990)

$$
\text { M.C., } \%=\frac{S_{B}-S_{A}}{S_{A}} \times 100 \quad(\text { dry base }) \ldots
$$

Where:

$\mathrm{S}_{\mathrm{B}}=$ Sample weight before drying

$\mathrm{S}_{\mathrm{A}}=$ Sample weight after drying

\section{Determination of un-threshed grain losses}

The un-threshed heads were collected, weighed and re-threshed. The percentage of grain losses was calculated (based on the calculated input weight of grain into the threshing unit).

\section{Visible grain damage}

Randomized samples of $100-\mathrm{g}$ was collected to determine visible grain damage. It was calculated as follows:-

$$
\text { DGL, } \%=\frac{\mathbf{D}_{\mathrm{G}}}{\mathbf{T}_{\mathrm{G}}} \times 100
$$

Where:-

$\mathrm{D}_{\mathrm{G}}=$ Weight of grain damaged in sample

$\mathrm{T}_{\mathrm{G}}=$ Total grain sample (Desta and Mishra, 1990)

\section{Grain losses in straw}

Grain losses in straw percentage were calculated as follows:- 
$\mathrm{SGL},(\%)=\frac{\mathrm{S}_{\mathrm{G}}}{\mathrm{T}_{\mathrm{G}}} \times 100$

Where:-

$\mathrm{S}_{\mathrm{G}}=$ Weight of grain losses in straw in sample

$\mathrm{T}_{\mathrm{G}}=$ Total grain sample (Desta and Mishra, 1990)

\section{The length of cut straw}

The length of cut straw was measured also. Three randomized samples were taken from the output straw for measuring the length of cut straw. Each sample contains about $100 \mathrm{~g}$. The mean of the cut straw length was calculated.

\section{Determination of threshing efficiency}

Machine threshing efficiency was estimated according to the following formula:

Threshing efficiency, $(\%)=\left(100-\frac{\text { Unthreshed grain in sample, } g}{\text { Total grain sample, } g} \times 100\right)$

(Desta and Mishra, 1990)

\section{Determination of cleaning efficiency}

Cleaning efficiency, $(\%)=\frac{\boldsymbol{W}}{\boldsymbol{W}_{o}} \times \mathbf{1 0 O}$

Where:-

$\mathrm{W}=$ Weight of grains from the main output opening after cleaning, $\mathrm{kg}$.

Wo $=$ Weight of grains and small chaff from the main output opening, $\mathrm{kg}$.

\section{Determination of fuel consumption:}

Fuel consumption per unit time is determined by measuring the volume of the consumed fuel during threshing time as follows:

The fuel tank refilled completely before and after the test, the difference between the two volumes is the fuel consumed.

\section{Power requirements}

The following formula was used to estimate the engine power according to Hunt (1983).

E.P $=F . C \times \frac{1}{3600} \times \rho_{f} \times L . C . V \times 427 \times \eta_{m} \times \eta_{t h} \times \frac{1}{75} \times \frac{1}{1.36} \quad K W$. 
Where:

E.P =Power consumption requirements during the threshing operation (k.W).

$\mathrm{Fc} \quad=$ Fuel consumption $\mathrm{L} / \mathrm{h}$.

$\rho_{f} \quad=$ Density of fuel, $\mathrm{kg} / \mathrm{L}$ (for solar $=0.85$ ).

L.C.V = Lower calorific value of fuel $(\mathrm{k} . \mathrm{cal} / \mathrm{kg})$ average L.C.V of solar is $11000 \mathrm{k.cal} / \mathrm{kg}$ ).

$\eta_{\text {th }}=$ Thermal efficiency of the engine, (considered to be about $35 \%$ for diesel engine).

$427=$ Thermo-mechanical equivalent, $\mathrm{kg} \cdot \mathrm{m} / \mathrm{kcal}$.

$\eta_{\mathrm{m}}=$ Mechanical efficiency of the engine, (considered to be 80 percentage for diesel engine).

\section{Specific energy}

Specific energy could be determined using the following equation Hunt (1983).

$$
\text { Specific energy }=\frac{\text { Power requirements }}{\text { Machine productivity }}\left(\frac{\mathbf{K W}}{\mathbf{t o n} / \mathbf{h}}\right) \ldots
$$

\section{Economic evaluation}

The total cost of threshing operating was estimated using the following equation, (Awady et al. 1982)

Threshing cost, $($ L.E/ton $)=$ Operating cost + Grain losses cost $\ldots \ldots$.

Operating cost was determined using the following equation:-

Machine cost (L.E / h)

Operating cost $=$ (L.E/ton)

Feed rate (ton / h)

Machine cost could be determined using the following equation (Awady 1978)

$$
C=\frac{P}{h}\left[\frac{1}{a}+\frac{i}{2}+t+r\right]+(O .9 \quad \text { W.S.F })+\frac{m}{144}
$$

Where:- 
$\mathrm{C}=$ Hourly cost, L.E/h $\quad \mathrm{p}=$ Price of machine, L.E.

$\mathrm{h}=$ Yearly working hours, $\mathrm{h} /$ year. $\mathrm{a}=$ Life expectancy of the machine, $\mathrm{h}$

$\mathrm{i}=$ Interest rate/year. $\quad \mathrm{F}=$ Foul price, L.E/l.

$\mathrm{t}=$ Taxes, over heads ratio. $\quad \mathrm{r}=$ Repairs and maintenance ratio.

$\mathrm{m}=$ Monthly average wage, L.E. $\quad 0.9=$ Factor accounting for lubrications.

$\mathrm{w}=$ Engine power, $\mathrm{hp} . \quad \mathrm{S}=$ Specific fuel consumption, $\mathrm{l} / \mathrm{hp} . \mathrm{h}$.

$144=$ Reasonable estimation of monthly working hours.

\section{RESULTS AND DISCUSSION}

\section{A. Machine performance.}

Results obtained showed that the drum speed of $1000 \mathrm{rpm}$ and crop moisture content of $13.4 \%$ are considered the optimum values during threshing operation before and after machine modification. Results recorded the minimum value of the total grain losses, minimum length of cut straw and maximum feeding rate $(\mathrm{kg} / \mathrm{min})$. The maximum threshing and cleaning efficiencies were also recorded. Decreasing drum speed and increasing crop moisture content more than the optimum values mentioned above, lead to increase total grain losses significantly under all experimental conditions. Thus is due to increasing un-threshed grains, as a result of non-uniform conditions during threshing operation.

\section{Feeding rate:}

Fig. (7) Shows that increasing the drum speed increase the feeding rate. Also, the feeding rate increased as a result of decreasing crop moisture content for thresher before and after machine modification under all experimental feeding rate conditions. At drum speeds of 700, 800, 900 and $1000 \mathrm{rpm}$, and crop moisture content of $13.4 \%$ the feeding rates were $18.5,22,25$ and $28 \mathrm{~kg} / \mathrm{min}$ respectively using the threshing machine before modification. It was $23,28,33$ and $38 \mathrm{~kg} / \mathrm{min}$ respectively using the developed machine. The conveyor belt angle was 20 degree. 


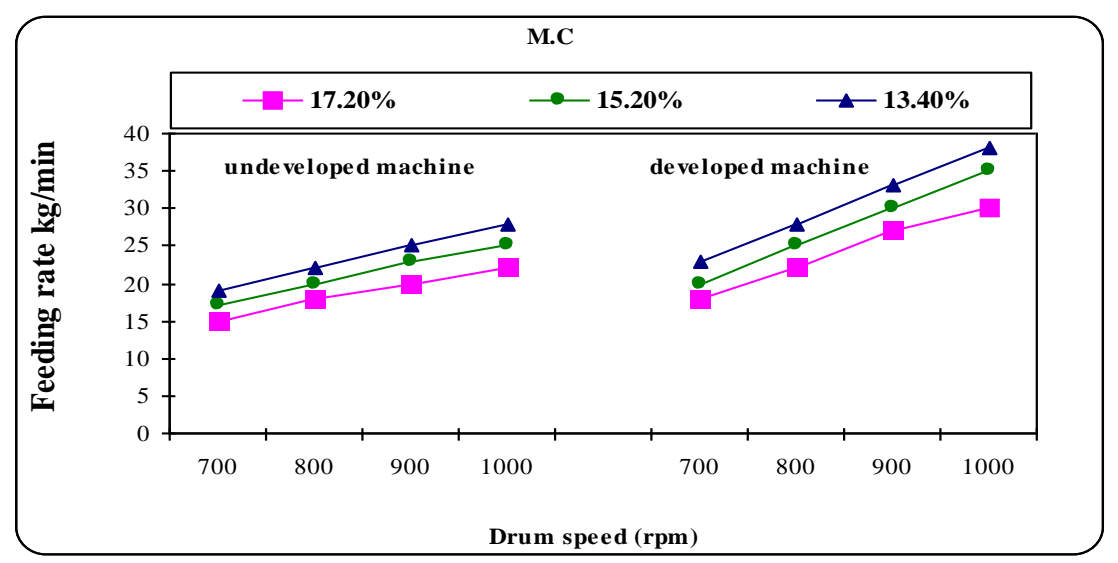

Fig. (7): Effect of drum speed on feeding rate at different moisture contents by using the thresher before and after modification.

Using the machine after modification increased the feeding rate comparing with the machine before development due to the uniform distribution of wheat materials along the feeding device, which guide wheat to the threshing chamber uniformity resulting in improve threshing operation.

\section{Un- threshed grain losses:}

Data presented in Fig. (8) Shows that increasing drum speed decreased un-threshered grain. Also there is a direct correlation between un-threshed grain and crop moisture content. Decreasing crop moisture content decreased un-threshed grain for thresher before and after modification under all experimental conditions. At drum speeds of 700, 800, 900 and $1000 \mathrm{rpm}$, and crop moisture content of $13.4 \%$ the obtained unthreshed grain were $3.8,2.9,2.2$ and $1.8 \%$ respectively before modification. It was $1.4,0.9,0.7$ and $0.5 \%$ respectively after modification at conveyor belt angle (20 degree) under the same previous conditions. Using the machine after modification decreased the unthreshed grain from $1.8 \%$ to $0.5 \%$ comparing with the machine before modification due to the uniform distribution of wheat materials along the developed feeding device, which enable plants to enter the threshing chamber from the panicles direction. Also the decrease in the percentage of unthreshed grains by increasing drum speed are attributed to the high stripping and impacting forces applied to the wheat plants, that tends to improve the threshing operation and decrease unthreshed grains. 


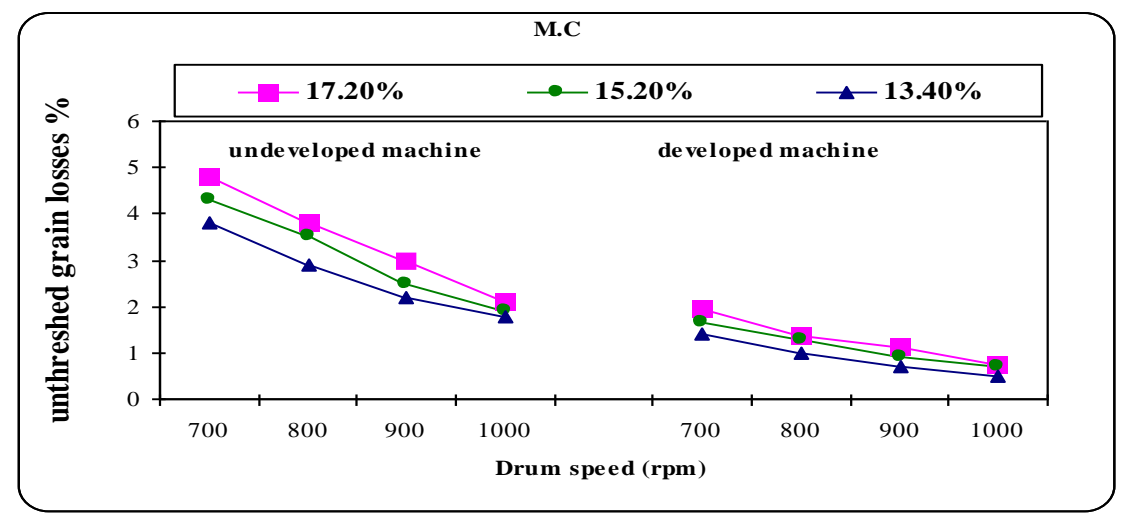

Fig. (8): Effect of drum speed on unthreshed grain losses at different moisture contents by using the thresher before and after modification.

\section{Grain losses in straw:}

Data presented in fig. (9) Shows that increasing drum speed increased grain losses in straw. Also increasing crop moisture content increased grain losses in straw for thresher before and after modification under all experimental conditions. At drum speeds of 700, 800, 900 and $1000 \mathrm{rpm}$, and crop moisture content of $13.4 \%$ the obtained grain losses in straw grain were $0.4,0.7,0.8$ and $1.0 \%$ respectively using the threshing machine before modification and $0.12,0.15,0.25$ and $0.30 \%$ respectively using the developed machine at conveyor belt angle (20 degree) under the same previous conditions. Using the machine after modification decreased the grain losses in straw from $1.0 \%$ to $0.30 \%$ comparing with the machine before modification due to the uniform distribution of wheat materials along the developed feeding device.

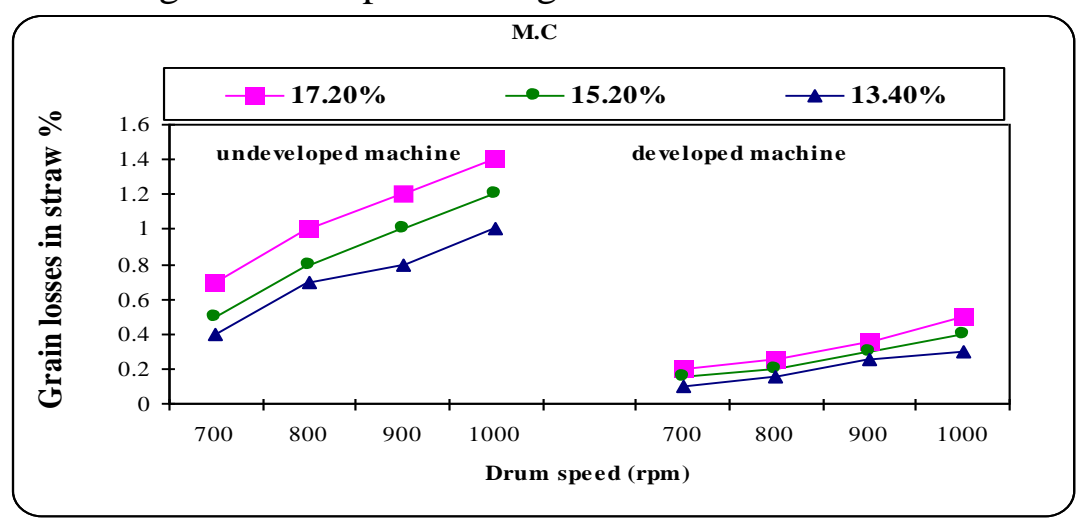

Fig. (9): Effect of drum speed on grain losses in straw at different moisture contents by using the thresher before and after modification. 


\section{Visible grain damage:}

Fig. (10) Shows that increasing drum speed increased visible grain damage. Also decreasing crop moisture content increased visible grain damage for thresher before and after modification under all experimental conditions. At drum speeds of 700, 800, 900 and $1000 \mathrm{rpm}$, and crop moisture content of $13.4 \%$ the obtained visible grain damage were 1.4, 1.7, 2.0 and $2.1 \%$ respectively using the threshing machine before development and 0.40, $0.45,0.55$ and $0.65 \%$ respectively using the developed machine at conveyor belt angle (20 degree) under the same previous conditions. The obtained data using the machine after modification decreased visible grain damage from $2.1 \%$ to $0.65 \%$ comparing with the machine before modification. The uniform distribution of wheat along the developed feeding led to the decrease in visible grain damage.

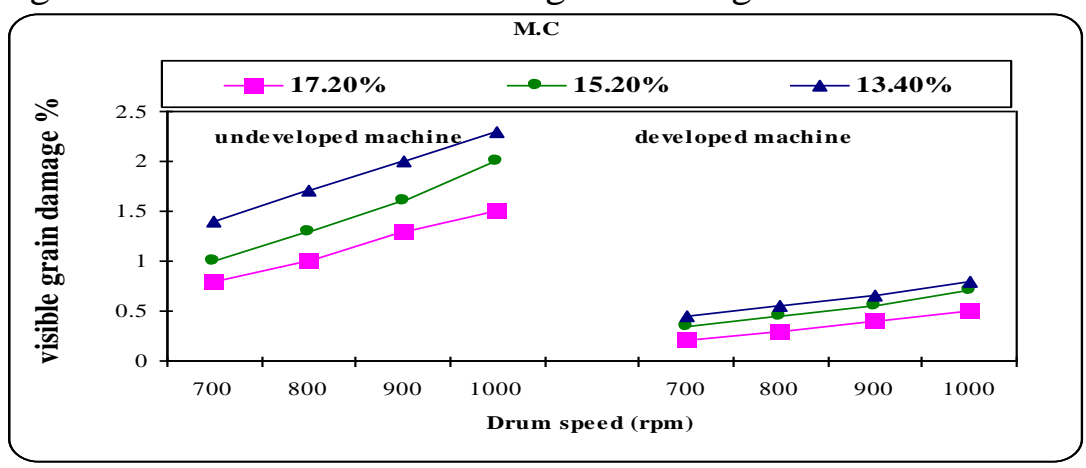

Fig. (10): Effect of drum speed on visible grain damage at different moisture contents by using the thresher before and after modification.

\section{Cutting length of straw:}

Data presented in Fig. (11) Shows that there is a indirect correlation between the thresher drum speed and the cutting length of straw. Increasing drum speed decreased the cutting length of straw. On the other hand decreasing moisture content decreased the cutting length of straw for thresher before and after modification under all experimental conditions. At drum speeds of 700, 800, 900 and $1000 \mathrm{rpm}$, and crop moisture content of $13.4 \%$ the obtained cutting length of straw was $2.3,2.1,2.0$ and $1.8 \mathrm{~cm}$ respectively using the threshing machine before modification and 1.7, 1.6, 1.4 and $1.2 \mathrm{~cm}$ respectively using the modification machine at conveyor belt angle (20 degree) under the same previous conditions. 


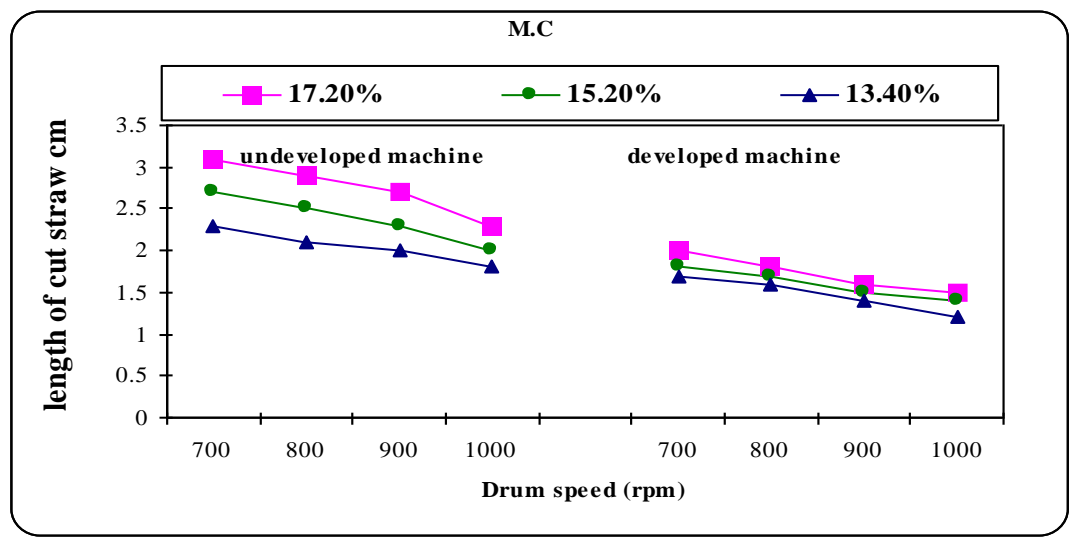

Fig. (11): Effect of drum speed on length of cut straw at different moisture contents by using the thresher before and after modification

This decrease in the cutting length of straw was due to the uniform distribution of wheat materials along the developed feeding device.

\section{Threshing and cleaning efficiencies:}

Threshing efficiency is a function of the un-threshed grain losses. It decreased as increasing grain moisture content. On the other hand it increased as increasing drum speed. While the cleaning efficiency expresses the amount of clean grains with minimum straw, stone and foreign materials thorough the threshing operation. The cleaning efficiency decreased as the grain moisture content increased. It increased as increasing drum speed. Fig. ( 12,13$)$ show also that, the developed machine increased the percentage of threshing and cleaning efficiencies comparing with the machine before modification under all experimental conditions due to the uniform distribution of wheat along the developed feeding device. That guide wheat to the chamber of thrashing in a uniform way resulting in low percentage of un-threshed grains and improve threshing operation. Increasing drum speed from 700 t0 $1000 \mathrm{rpm}$ and decreasing crop moisture content from 17.2 to $13.4 \%$ increased the percentage of threshing and cleaning efficiencies from $95.8,95.3 \%$ to $98.2,98.4 \%$ respectively using the threshing machine before modification and from $98.1,98.6 \%$ to 99.5 , $99.7 \%$ respectively using the threshing machine after modification at conveyor belt angle (20 degree) due to the uniform distribution of wheat materials along the shaker under the same previous conditions. 


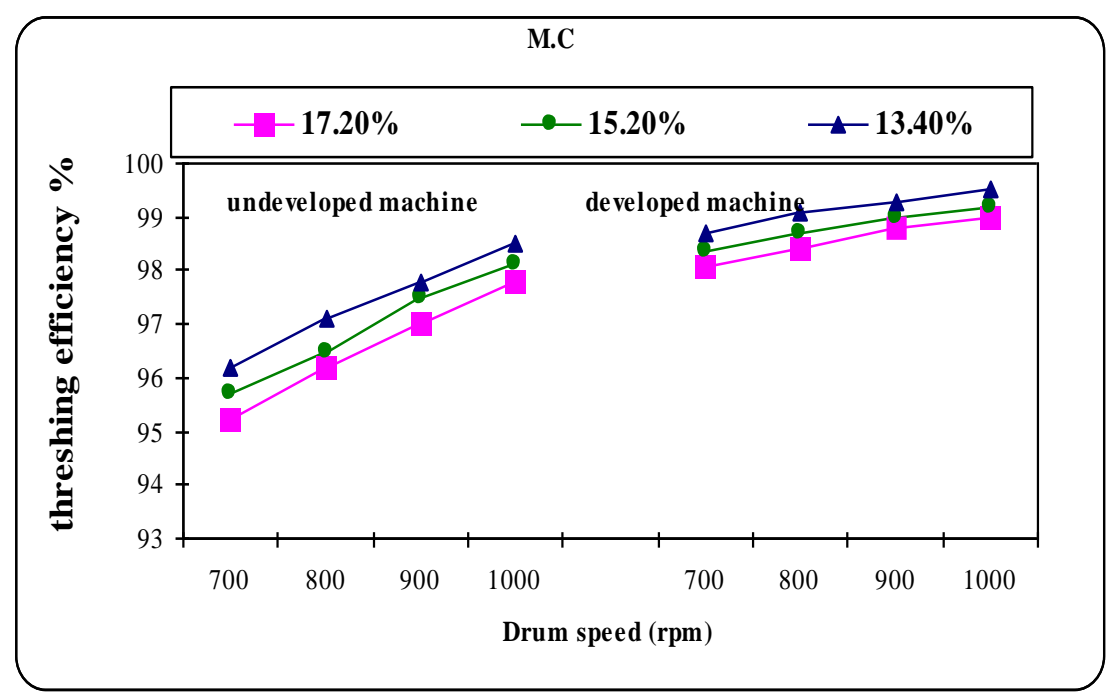

Fig. (12): Effect of drum speed on threshing efficiency at different moisture contents by using the thresher before and after modification.

The obtained data show also that the developed machine increased the percentage of threshing and cleaning efficiencies comparing with the machine before modification because of the uniform distribution of wheat materials along the threshing chamber which enable the threshing drum to knock wheat materials more times that tends to improve threshing process and increase threshing and cleaning efficiencies.

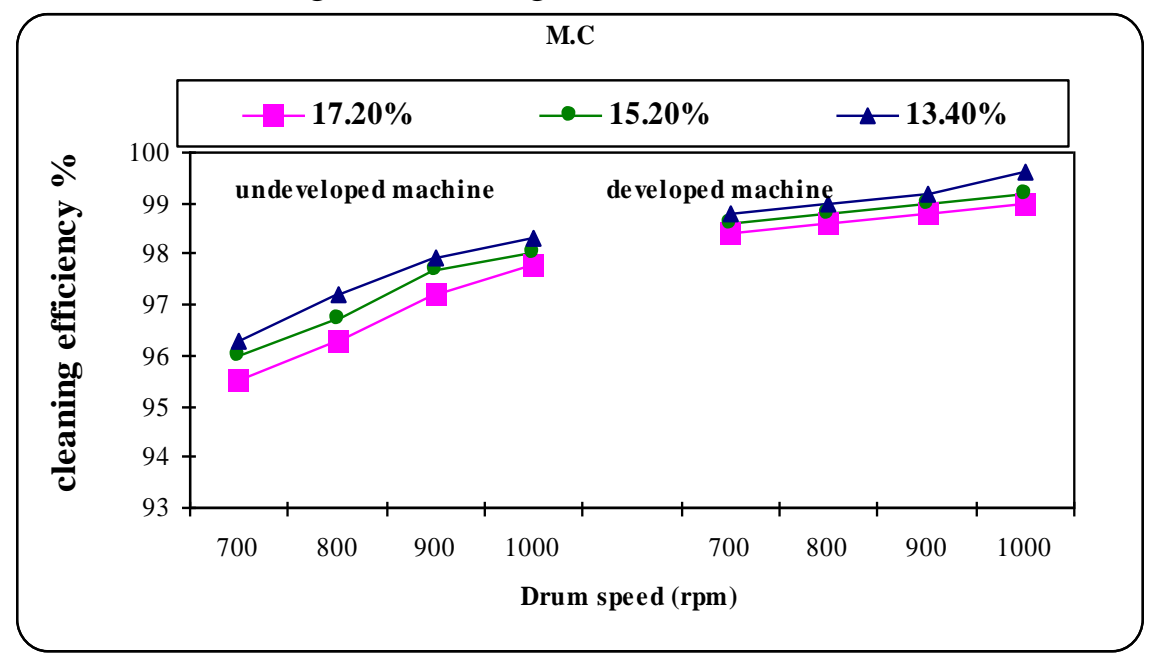

Fig. (13): Effect of drum speed on cleaning efficiency at different moisture contents by using the thresher before and after modification 


\section{Fuel consumption ( lit/h ) and energy requirements:}

The energy requirements and fuel consumption are a measure for all parameters affecting the threshing operation. It increased as increasing the material feed rate due to increasing threshing drum speed and grain moisture content. Results obtained in fig. $(14,15)$ show that increasing material feed rate increased rate of fuel consumption and the percentage of energy requirements under all experimental conditions. The increase in the percentage of energy requirements by increasing material feed rate is attributed to the excessive wheat in the threshing chamber, that increase the load on the threshing drum caused more fuel consumed. Results presented in fig. (15) Show that increasing drum speed increased the energy requirements under all experimental conditions. Increasing drum speed from 700 to $1000 \mathrm{rpm}$ increased the percentage of energy requirements from 13.9 to $18.96 \mathrm{~kW}$ using the threshing machine before modification. This speed increased from 13.9 to $18.65 \mathrm{~kW}$ using the modification machine at conveyor belt angle (20 degree) under the same previous conditions. The increase in the percentage of energy requirements by increasing drum speed is attributed to the high stripping and impacting forces applied during threshing operation, that tend to consume more fuel and increase energy requirements. Results also show that the modification machine decreased the percentage of energy requirements comparing with the machine before modification due to increased fuel consumption with the machine before modification.

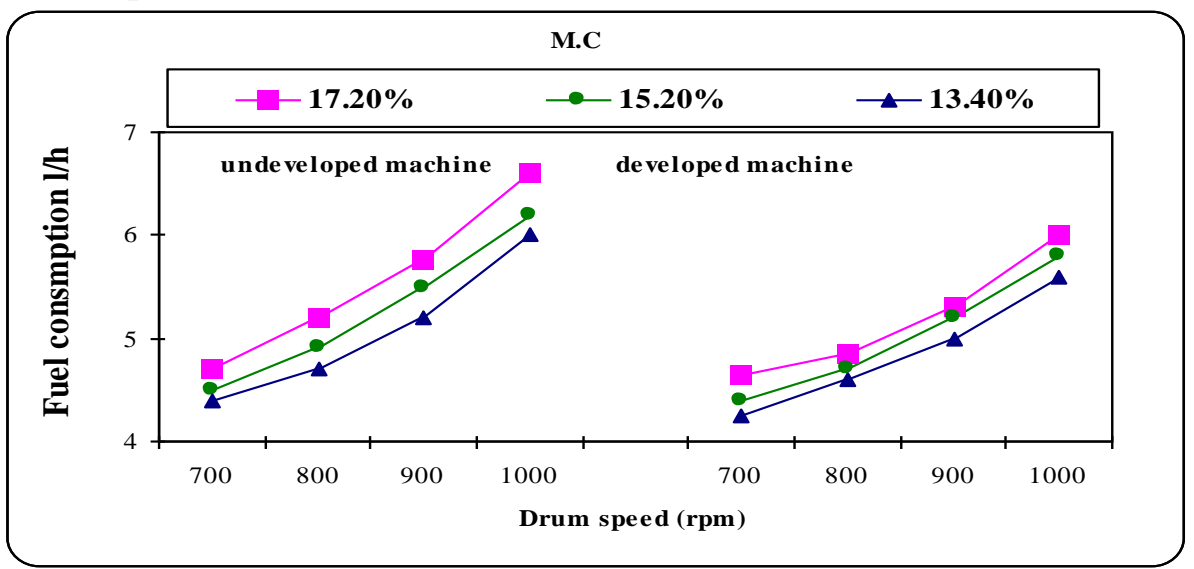

Fig. (14): Effect of drum speed on fuel consumption at different moisture content by using the thresher before and after modification. 


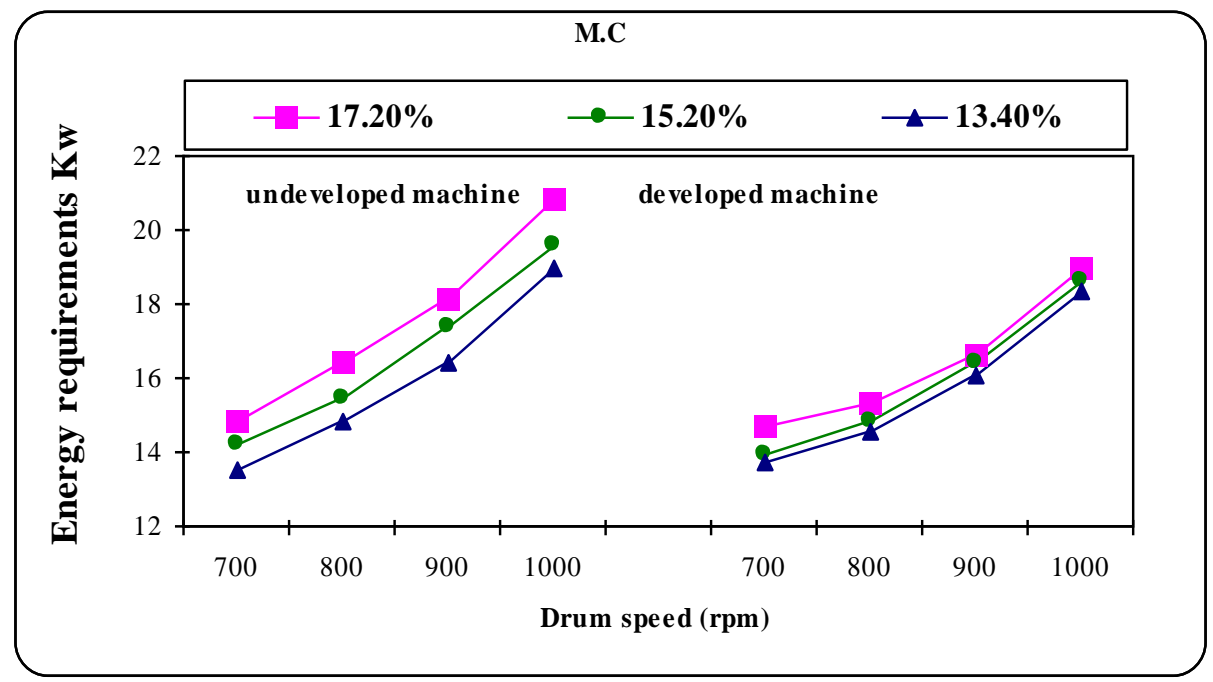

Fig. (15): Effect of drum speed on energy requirements at different moisture contents by using the thresher before and after modification.

\section{B. Threshing cost LE/ton:}

One of the most important factors that judge the success of the machine modification is the total threshing costs. It was also calculated. Assuming that the purchase price $(\mathrm{P})$, anticipated length of time owned (a) and yearly working hours (h) for different equipment are as presented in table (1):

\begin{tabular}{|l|c|c|c|}
\hline Equipment & $\begin{array}{c}\mathrm{P} \\
\text { (LE) }\end{array}$ & $\begin{array}{c}\mathrm{a} \\
\text { (year) }\end{array}$ & $\begin{array}{c}\mathrm{h} \\
\text { (h/year) }\end{array}$ \\
\hline $\begin{array}{l}\text {-Tractor } \\
\text { NASR 60 hp }\end{array}$ & 100000 & 10 & 1000 \\
\hline $\begin{array}{l}\text {-Original } \\
\text { thresher }\end{array}$ & 20000 & 10 & 500 \\
\hline $\begin{array}{l}\text {-Developed } \\
\text { thresher }\end{array}$ & 22000 & 10 & 500 \\
\hline
\end{tabular}

* According to equation (10) Assuming that: 
- Rate of interest $\quad=15 \%$

- Mean of fuel consumption for original thresher and developed thresher at high productivity $=6 \mathrm{lit} / \mathrm{h}$ approximately

- Price per liter fuel $=1.1 \mathrm{LE}$

- Wage of laborer $=5 \mathrm{LE} / \mathrm{h}$

- Number of labors $=2$ labors for original thresher and

1 laborer for developed thresher

Table (2) indicated that, the minimum value of the losses cost was 45.87 LE/ton for undeveloped thresher at $1000 \mathrm{rpm}$ and $13.4 \%$ moisture content while the minimum value of the losses cost was $13.58 \mathrm{LE} /$ ton for developed thresher at $1000 \mathrm{rpm}$ and $13.4 \%$ moisture content.

Table (3) indicated that threshing cost for the developed machine was 36.4 LE/ton compared to 79.2 LE/ton for undeveloped machine that was due to higher losses of grains and lowest feeding rate for undeveloped machine. Cost determinations were obtained as the total cost per unit of operating time (LE/h) and threshing cost (LE/ton) as indicated in table (3).

\section{Table (2) Losses cost for undeveloped thresher and developed thresher}

\begin{tabular}{|l|c|c|c|c|c|c|}
\hline Machine & $\begin{array}{c}\text { Un-thereshed } \\
\text { grain losses } \\
\%\end{array}$ & $\begin{array}{c}\text { Grain } \\
\text { losses in } \\
\text { straw } \\
\%\end{array}$ & $\begin{array}{c}\text { Visible } \\
\text { grain } \\
\text { damage } \\
\%\end{array}$ & $\begin{array}{c}\text { Total } \\
\text { grain } \\
\text { losses } \\
\%\end{array}$ & $\begin{array}{c}\text { Weight of } \\
\text { total grain } \\
\text { losses } \\
\mathrm{Kg} / \text { ton }\end{array}$ & $\begin{array}{c}\text { Losses } \\
\text { cost } \\
\text { LE/ton }\end{array}$ \\
\hline $\begin{array}{l}\text { Undeveloped } \\
\text { thresher }\end{array}$ & 1.8 & 1.0 & 2.1 & 4.9 & 18.13 & $45.87^{*}$ \\
\hline $\begin{array}{l}\text { Developed } \\
\text { thresher }\end{array}$ & 0.5 & 0.3 & 0.65 & 1.45 & 5.37 & $13.58^{*}$ \\
\hline
\end{tabular}

$$
\text { * Price per kilogram grain }(2012) \quad=2.53 \mathrm{LE} / \mathrm{kg}
$$


Table (3): Criterion function cost for two threshing machines.

\begin{tabular}{|c|c|c|c|c|c|c|}
\hline machine & $\begin{array}{c}\text { Operating } \\
\text { cost }\end{array}$ & $\begin{array}{c}\text { Feeding } \\
\text { rate }\end{array}$ & $\begin{array}{c}\text { Criterion } \\
\text { function } \\
\text { cost } \\
\text { LE/ton }\end{array}$ & $\begin{array}{c}\text { Total* } \\
\text { grain } \\
\text { losses } \\
\text { Kg/ton }\end{array}$ & $\begin{array}{c}\text { Losses } \\
\text { cost }\end{array}$ & $\begin{array}{c}\text { Threshing } \\
\text { cost }\end{array}$ \\
\hline $\begin{array}{c}\text { Undeveloped } \\
\text { thresher }\end{array}$ & 21 & 1.680 & 12.5 & 18.13 & 45.87 & 58.37 \\
\hline Tractor & 35 & - & 20.83 & - & - & 20.83 \\
\hline Total & 56 & - & 33.33 & 18.13 & 45.87 & 79.2 \\
\hline $\begin{array}{c}\text { Develop-ed } \\
\text { thresher }\end{array}$ & 17 & 2.280 & 7.47 & 5.37 & 13.58 & 21.05 \\
\hline Tractor & 35 & - & 15.35 & - & - & 15.35 \\
\hline Total & 52 & - & 22.81 & 5.37 & 13.58 & 36.4 \\
\hline
\end{tabular}

* Total grain losses $=$ Un-threshed grain losses + grain losses in straw + visible grain damage

\section{REFERENCES}

Abo El-Naga, M.H.M., M.K.Afify and S.E.Badr (2004) "Utilization of Local wheat thresher machine for threshing mungbean" Misr J. Ag. Eng. 21 (2): 423-436.

AOAC (1990) "Association official Analytical chemists".15th edn. Wash. Dc, U.S.A.

Daghan, I; T.Hakan and Y. Canbaz (2012) "Upper extremity injuries due to threshing machine" Turkish Journal of trauma 2012; 18 (1):55-60.

Desta, K. and T.N. Mishra (1990) "Development and performance Evaluation of a Sorghum thresher" AMA, 21 (3): 33-37. 
El-Awady, M. N.(1978). Tractor and farm machinery. Text book, Faculty of Agriculture, Ain- Shams University, Cairo, Egypt. PP: 164-167

El-Awady, M. N; E. Y. Ghoniem and A. I. Hashim (1982)"A critical comparison between wheat combine harvester under Egyptian condition". R. S. No.1920 Ain Shams Univ. Col.Agr. Pp. 1-12

El-Mufti, I; S. I. Ahmad and A. Majid (1989) "Farm accidents in Pakistan"Agric Mech. Asia Africa Latin America 20, 73-75.

Hunt, D. (1983)"Farm power and machinery management."(eight-edition) pp.135 - 137.

Khattab A. M.; M. M. EL-Sharabasy and M. M. Mahmoud (2007) "Development of feeding device in a Turkishing machine" Misr. J.Agric. Eng., 235-257.

Mohan, D. and R. Patel (1992) "Design of safer agricultural equipment" application of ergonomics and epidemiology. Int. J. Ind.Ergonom. 10,301-309.

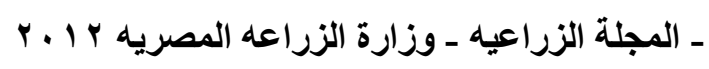

\section{الملخص العربي}

تطوير آلة الدراس والتذريه لتحسين أدائها تحت الظروف الزراعية المصرية

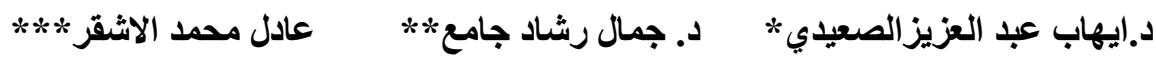
يعتبر القمح من اهم محاصيل الحبوب الغذائيه التى يعتمد عليها الثعب المصرى فى غذائه و على الثى

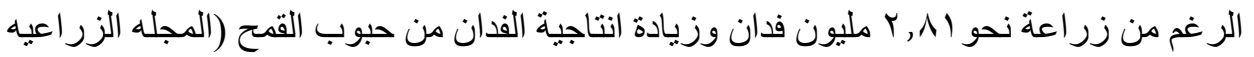

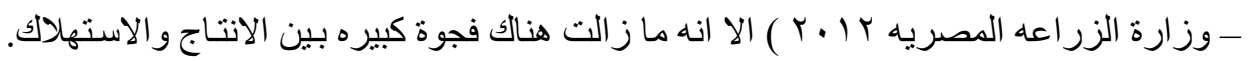

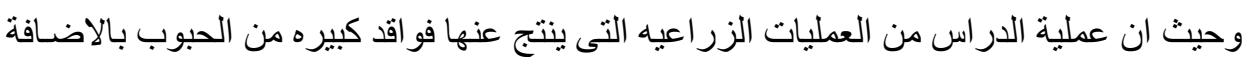

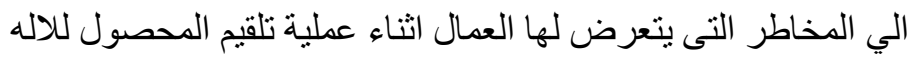

\footnotetext{
*مدرس- قسم الهندسة الزراعيةـ كلية الزراعة- جامعة المنوفية ـمصر. ** أستاذ مساعد ـ قسم الهندسة الزراعية_ كلية الزراعةـ جامعة المنوفية ــمصر.

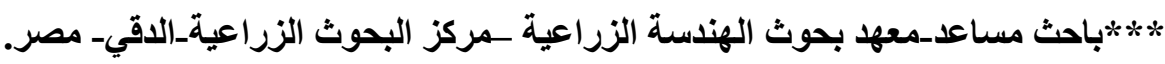




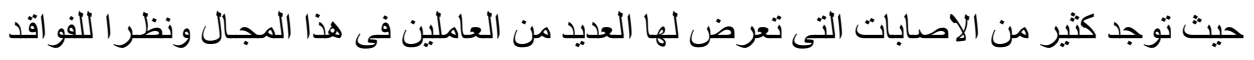

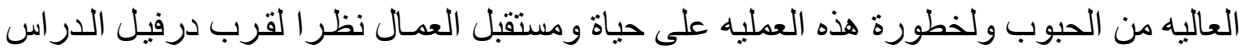

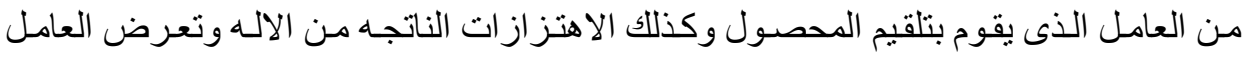

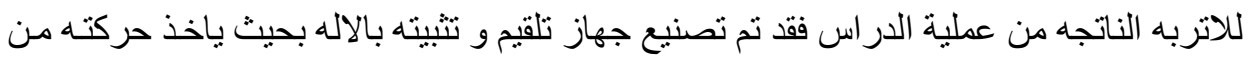

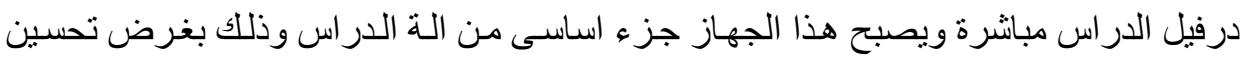

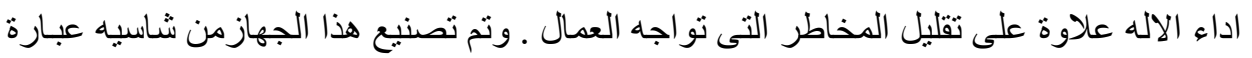

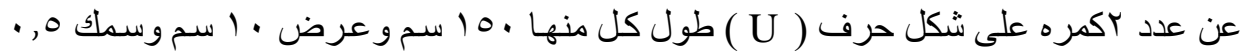

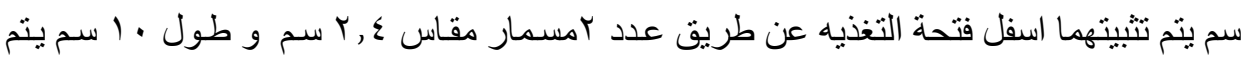

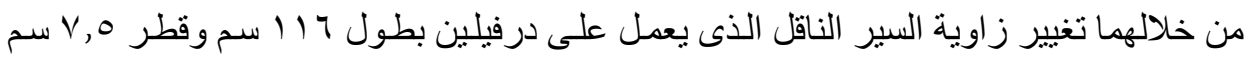

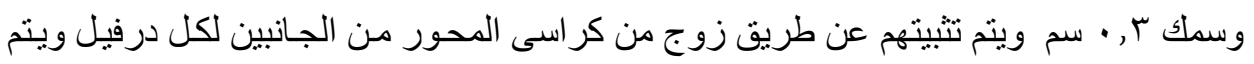

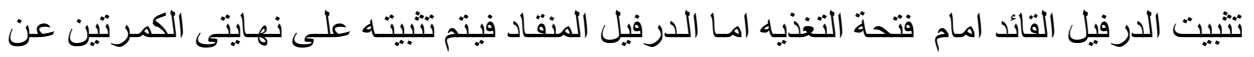

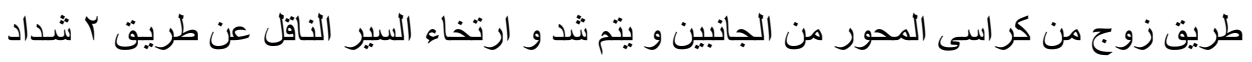

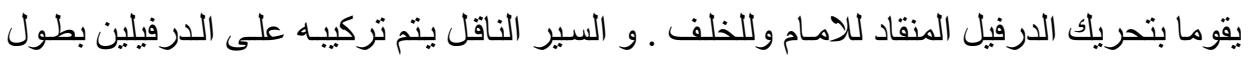

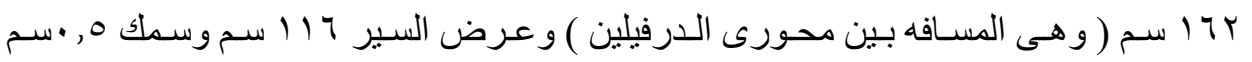

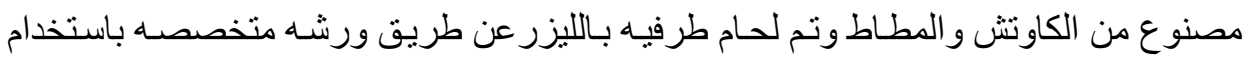

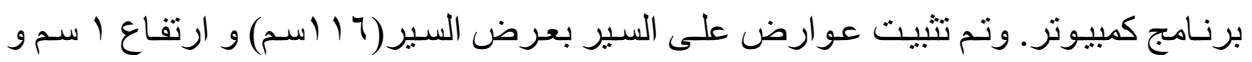

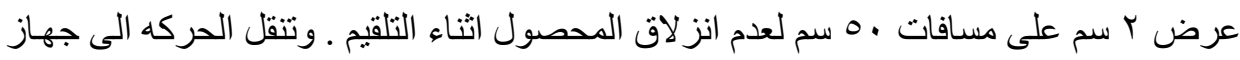

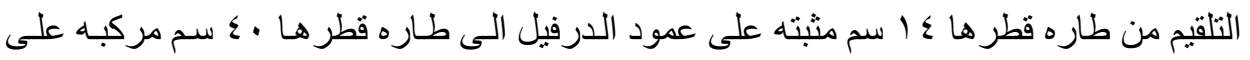

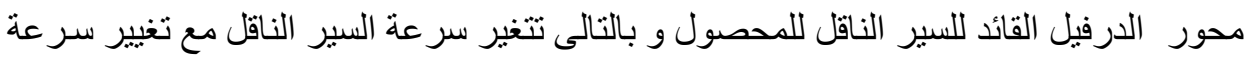

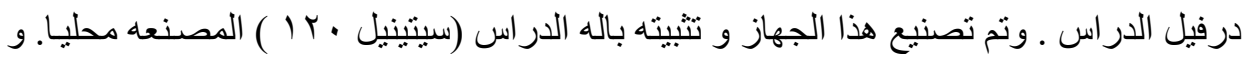

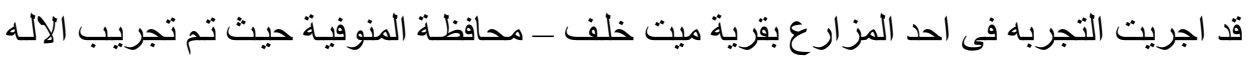

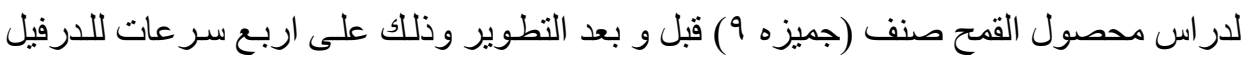

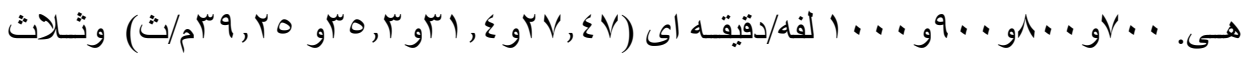

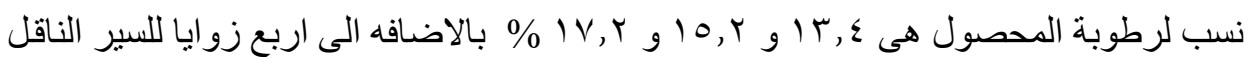

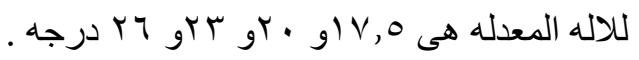

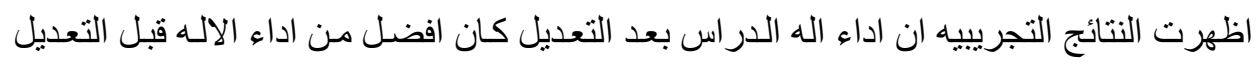

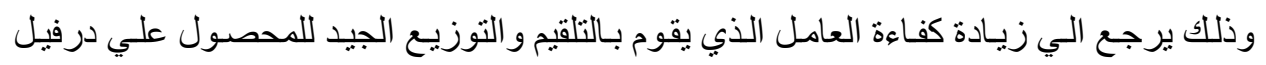

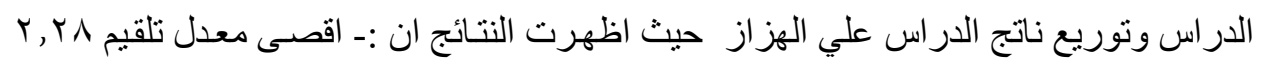

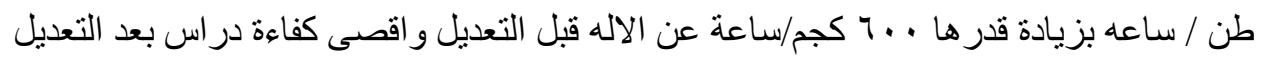

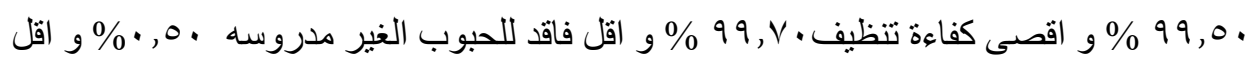
فاقد للحبوب في القش بلغ • r, • \% و ان اقل نسبة كسر للحبوب ه7 , • \% و و اقل طول لقطع 


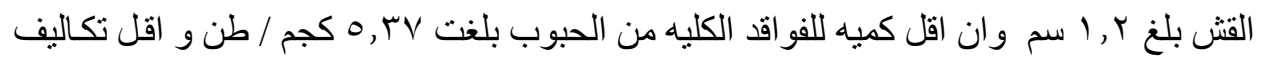

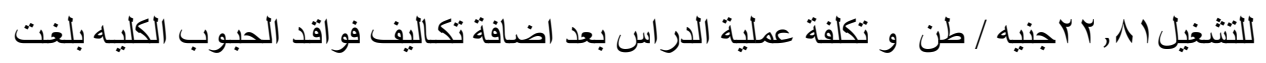

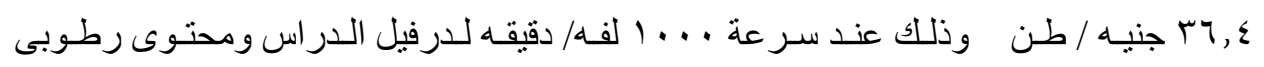

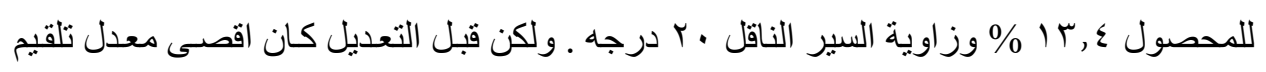

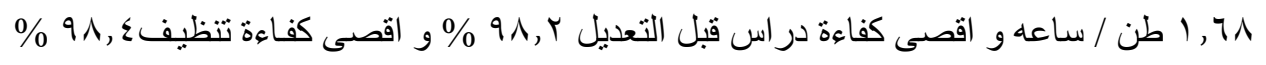

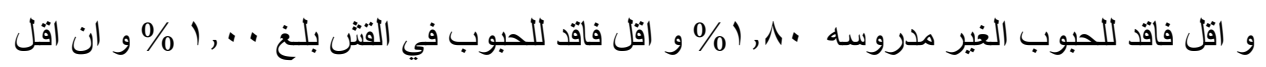

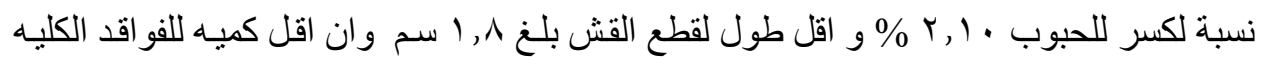

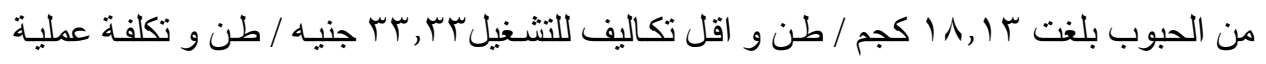

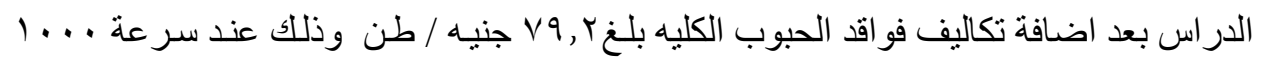

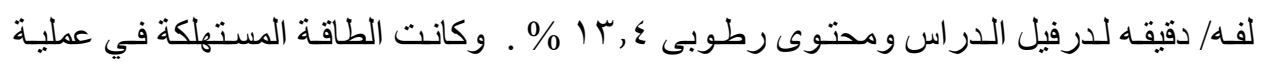

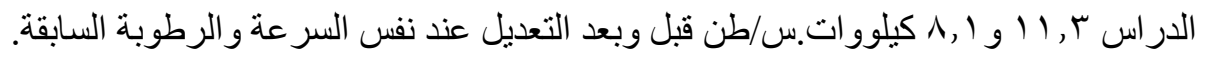

